\title{
Molecular Characterization of Tob1 in Muscle Development in Pigs
}

\author{
Jing Yuan ${ }^{1,2}$, Ji-Yue Cao ${ }^{1}{ }^{*}$, Zhong-Lin Tang ${ }^{2, *}$, Ning Wang ${ }^{3}$ and Kui $\mathrm{Li}^{2}$
}

1 College of Veterinary Medicine, Huazhong Agricultural University, Wuhan, Hubei 430070, China; E-Mail: yuanjing@mail.hzau.edu.cn

2 Key Laboratory for Farm Animal Genetic Resources and Utilization of Ministry of Agriculture of China, Institute of Animal Science, Chinese Academy of Agricultural Sciences, Beijing 100193, China; E-Mail: kuili@iascaas.net.cn

3 College of Animal Science, Northeast Agricultural University, Haerbin, Helongjiang 150030, China; E-Mail: ningwang2001@yahoo.com

* Authors to whom correspondence should be addressed; E-Mails: caojiyue@ mail.hzau.edu.cn (J.-Y.C.); zhonglinqy_99@sina.com (Z.-L.T.); Tel.: +86-27-87281593 (J.-Y.C.); +86-10-62818180 (Z.-L.T.); Fax: +86-10-62818180 (Z.-L.T.).

Received: 25 April 2011; in revised form: 18 May 2011 / Accepted: 20 May 2011 / Published: 4 July 2011

\begin{abstract}
Cell proliferation is an important biological process during myogenesis. Tob1 encoded a member of the Tob/BTG family of anti-proliferative proteins. Our previous LongSAGE (Long Serial Analysis of Gene Expression) analysis suggested that Tobl was differentially expressed during prenatal skeletal muscle development. In this study, we isolated and characterized the swine Tobl gene. Subsequently, we examined Tob1 chromosome assignment, subcellular localization and dynamic expression profile in prenatal skeletal muscle (33, 65 and 90 days post-conception, dpc) from Landrace (lean-type) and Tongcheng pigs (obese-type). The Tobl gene was mapped to pig chromosome 12 (SSC12). The Tobl protein was distributed throughout the nucleus and cytoplasm of PK15 cells. During prenatal skeletal muscle development, Tobl was up-regulated and highly expressed in skeletal muscle at $90 \mathrm{dpc}$ in Tongcheng pigs but peaked at $65 \mathrm{dpc}$ in Landrace pigs. This result suggested that there were different proliferation patterns during myogenesis between Tongcheng and Landrace pigs. During postnatal skeletal muscle development, the expression of Tobl increased with aging, indicating that the proliferation potential of myoblasts decreased in postnatal muscle development. In tissues of adult wuzhishan miniature pigs, the Tobl gene was highly expressed in skeletal muscle. The expression of
\end{abstract}


Tobl was significantly increased at day 6 during C2C12 differentiation time, suggesting a possible role in skeletal muscle development. Therefore, this study indicated that Tob1 perhaps played an important role in skeletal muscle development.

Keywords: pig; Tob1; muscle development; expression profile; chromosome mapping; subcellular localization

\section{Introduction}

Tob1 (transducer of ERBB2, 1) is a member of the Tob/BTG gene family that had the potential to regulate cell growth. The Tob/BTG gene family consists of at least six members in vertebrates: BTG1, BTG2/TIS2 1/PC3, BTG3/ANA, PC3B, Tob1 and Tob2 [1]. The Tob/BTG proteins have a highly conserved 110-amino acid N-terminal region, designated the Tob/BTG homology domain, considered as the domain responsible for their anti-proliferative effects [2], while their C-terminal regions were necessary and sufficient to regulate the stabilities of BTG1, BTG2, Tob1, and Tob2 proteins [3].

The Tob/BTG genes are involved in cell growth (anti-proliferation) and differentiation. It had been previously reported that the BTG2 and BTG3 genes were associated with myoblast proliferation [4]. Tob1 was first isolated as a protein associated with the ErbB2 growth factor receptor [5]. The anti-proliferative function of Tob1 was negatively regulated through phosphorylation by extracellular signal-regulated protein kinase (Erk) 1 and 2 [6]. Exogenously expressed Tob1 could control cell growth, and inhibited the proliferation effect to stimulate growth through its interaction with p185erbB2 [5]. Tob1 inhibited T cell activation, blocked cell cycle [7], repressed transcription of cytokines and cyclins and was a substrate of the MAPK (mitogen-activated protein kinases) pathway [8]. The Tob1 gene was expressed in various segments of the brain and may be involved in learning and memory in mammals [9]. Tob1 also negatively regulated osteoblast proliferation and differentiation by inhibiting the activity of the receptor-regulated Smad proteins [10,11]. Most research on Tobl had focused on its role in cancer, Tobl perhaps is an important tumor suppressor, as mice lacking the Tobl gene had been reported to be more prone to cancer than wide-type mice [12] and Tobl had lower expression levels in lung cancer tissue than in adjacent normal lung tissues in humans [12,13]. Tobl was expressed maternally and continuously throughout embryonic development period [14], Over-expression of Tob1 in zebrafish embryos resulted in ventralized phenotypes, while Tobl knockdown led to embryonic dorsalization [15], which suggested that Tobl played an important role during embryonic development. These observations indicated the importance of Tobl in many biological processes.

Our previous LongSAGE analysis (LongSAGE was an adaptation of the SAGE approach that allows $21 \mathrm{bp}$ tags to be obtained from individual transcripts) suggested that Tobl was differentially expressed during the development of fetal skeletal muscle [16], but there were no reports on the biological role of Tob1 in skeletal muscle development. To understand the biological function of Tobl during myogenesis, we isolated and characterized the Tobl gene in swine. 


\section{Results and Discussion}

\subsection{Tob1 mRNA Sequences Analysis}

The full-length mRNA of swine Tobl contained a 1041-bp open reading frame encoding a 346-amino acid protein with a predicted molecular weight of $38.257 \mathrm{kDa}$ and an isoelectric point of 6.45 . The mature mRNA sequence contained a 5'-untranslated region (5' UTR) of 401 bp and a 3' UTR of 774 bp with an AATAAA polyadenylation signal. The obtained sequence had $60 \mathrm{bp}$ using the GLGI method. The isolated gene sequence was submitted to Genebank (Genebank No.: EF486515). The swine Tob1 gene sequence had $94 \%$ similarity with the human Tobl gene. We predicted the conserved domain from the deduced amino acid sequence using BlastP. Morever, the RPS-blast program predicted that swine Tob1 amino acids 1-118 and 1-140 contained typical BTG1 and anti-proliferative conserved domains, respectively (Figure 1), suggesting that this protein was a member of the BTG family.

Figure 1. The conserved functional domains of the swine Tob1 protein.

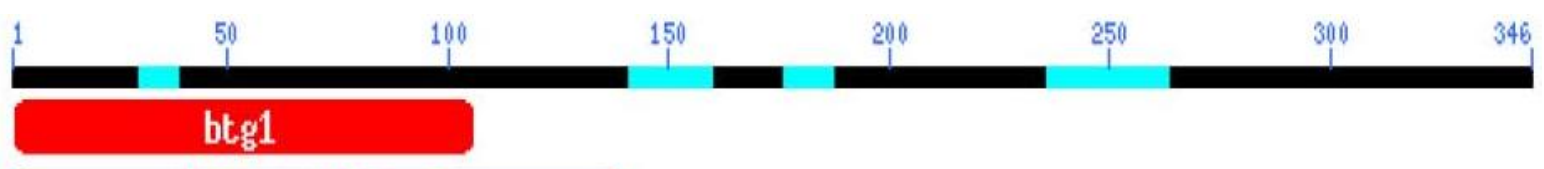

Anti_proliferat

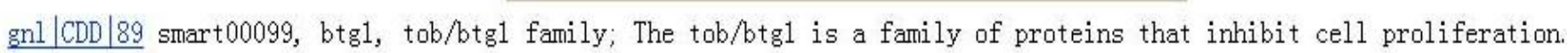

$$
\begin{aligned}
& \text { CD-Length }=108 \text { residues, } 100.0 \% \text { aligned } \\
& \text { Score }=171 \text { bits }(434), \text { Expect }=1 e^{-43}
\end{aligned}
$$

Query: 1 MQLEIQWALNFIISYL-YNKLPRRRWIFG EFIERZLKKXYEGHWYPEKPYKG SGFRCI 58

Sbjet: 1 MKLEIAAAWNFITSLLRKHNKLSKRRVEIFAEKL TRLLKEKYKNHWYPEKPYKGSGFRCI 60

Query: 59 HIGEKWDPVIEQASKESGLDIDDWRGMLPDLSWWIDPFEVSYQIGEK 106

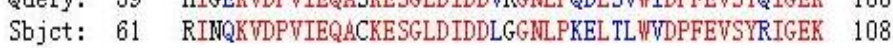

\begin{tabular}{|c|c|c|c|}
\hline & & $\begin{array}{l}\text { CD-Length }=159 \text { residues, } 89.9 \% \text { aligned } \\
\text { Score }=207 \text { bits }(527), \text { Expect }=2 e-54\end{array}$ & \\
\hline Query: & 1 & MQLEIQVALNFIISYLYNK--LPRRRWIFG EELERLISKXYEGHWYPEKPYKGSGFRCI & 58 \\
\hline Sbjct: & 1 & MKLEIABMVNFITSLLRKKGQLSKRRVEKFAEKLTRLLKEKYKNHWYPEKPSKGSGFRCI & 60 \\
\hline Query: & 59 & HIGEKWDPVIEQASKESGLDIDDVRGNLPQDLSWWIDPFEVSYQIGEKGPVKVL YDDNN & 118 \\
\hline Sbjet: & 61 & RINHKQDPDIEQAAQCIGLSWDDLDLGLPKELTLWVDPFEWSYRIGEKGSIFVLYSFANK & 120 \\
\hline Query: & 119 & ENGC-ELDKEIKNSFNPEAQVFM & \\
\hline Sbjct: & 121 & DGSNDELDKEIK SALNKK TQDYL & \\
\hline
\end{tabular}

gnl |CDD|15312 pfam01211, Anti_proliferat, BTG1 family. A novel family of anti-proliferative proteins..

\subsection{Temporal and Spatial Expression}

While Tobl had been reported to be expressed in skeletal muscle of mice [17] and humans [5], the expression pattern of Tobl during the development of skeletal muscle has not been reported for swine. This study analyzed the expression level of Tobl in skeletal muscle at different developmental stages and found that the swine Tobl gene had different expression levels at various stages of skeletal muscle 
development in different pig breeds. Both LongSAGE (Table 1) and the quantitative PCR (Figure 2) analysis suggested that the Tob1 gene peaked at $90 \mathrm{dpc}$ in Tongcheng pigs and $65 \mathrm{dpc}$ in Landrace pigs during prenatal skeletal muscle development. The Tobl gene was differentially expressed in skeletal muscle in Tongcheng and Landrace fetal pigs, indicating that the gene perhaps involved in the phenotypic differences in muscle fiber between Chinese and foreign breeds of pigs. The function of Tobl gene was anti-proliferation, thus expression difference perhaps was one of the reasons that associated to the birth weight difference of Tongcheng and Landrace pigs. In postnatal skeletal muscle in Tongcheng pigs, we found that Tobl was up-regulated with increased age (Figure 2) which suggested that the Tobl gene was related to the development of skeletal muscle.

Table 1. Significance analysis for the differential expression of Tobl in the embryonic skeletal muscle LongSAGE libraries from Tongcheng and Landrace pigs at different developmental stages.

\begin{tabular}{lllllll}
\hline & T33 & T65 & T90 & L33 & L65 & L90 \\
\hline T33 & 1 & 0.5058 & $0.0045^{* *}$ & 1 & 0.3232 & 0.4929 \\
& $(1)$ & $(3)$ & $(11)$ & $(1)$ & $(3)$ & $(2)$ \\
T65 & & 1 & $0.0287^{*}$ & 0.3162 & 0.6567 & 0.5321 \\
T90 & & & 1 & $0.0034^{* *}$ & $0.0273^{*}$ & $0.0129 *$ \\
L33 & & & & 1 & 0.3384 & 0.4616 \\
L65 & & & & & 1 & 0.5546 \\
L90 & & & & & & 1 \\
\hline
\end{tabular}

( ) represents sequence counts of LongSAGE tag; * indicates $p<0.05$; ** indicates $p<0.01$.

Figure 2. The expression profile of Tobl in longissimus dorsi muscle from Tongcheng and Landrace pigs at different development stages by real time PCR. T33, T65, T90, N2, N28, A represented longissimus dorsi muscle from Tongcheng pigs at 33, 65, 90dpc, at postnatal 2, 28 days and adult periods, respectively. L33, L65, L90 represented longissimus dorsi muscle from Landrace pigs at 33, 65, $90 \mathrm{dpc}$, respectively.

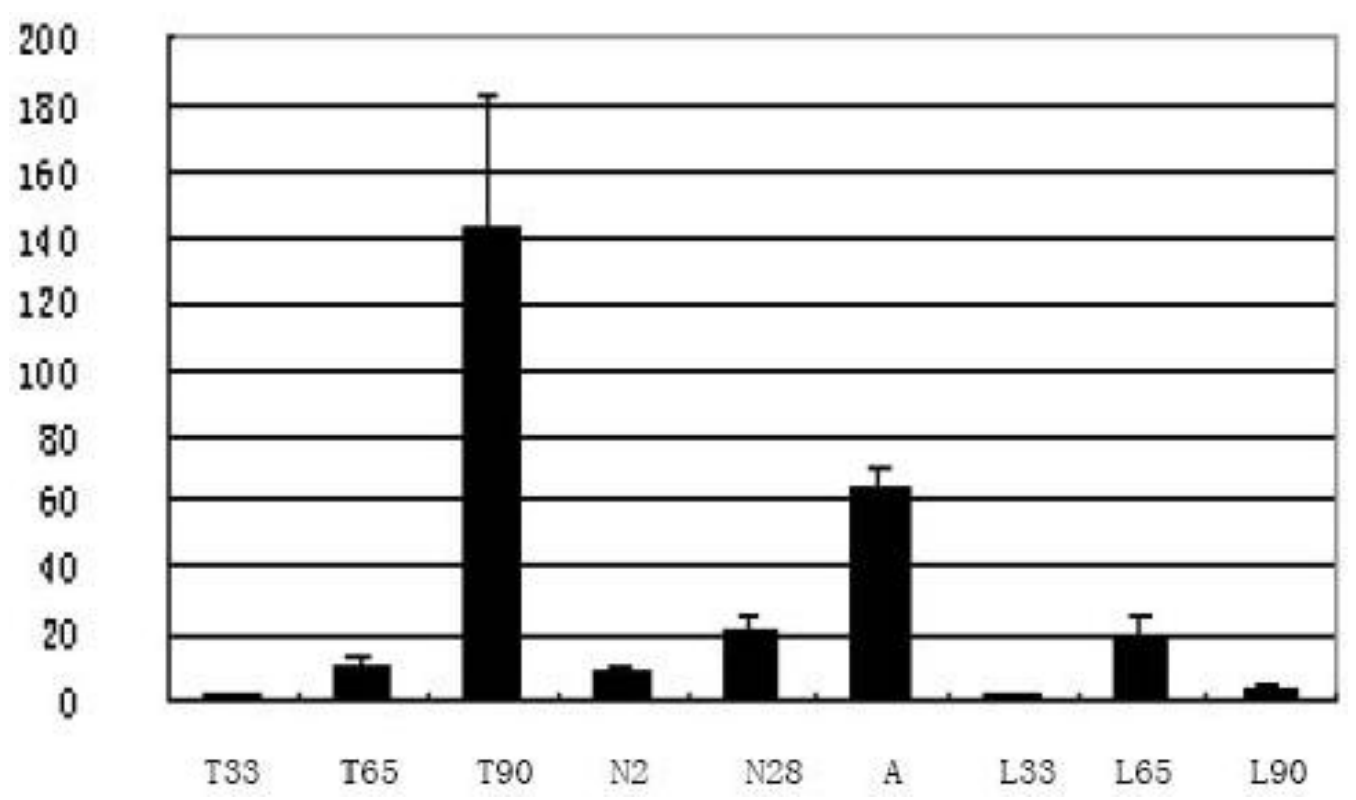


The tissue distribution of Tobl mRNA suggested that it was highly expressed in skeletal muscle, heart, and liver and weakly expressed in spleen, lung, fat tissues of adult pigs (Figure 3). The human Tobl gene is highly expressed in heart, liver and kidney but weakly expressed in lung, fat and spleen using the UCSC Genome Bioinformatics [18]; thus, Tob1 exhibited similar tissue expression patterns between pigs and humans.

Figure 3. The expression profile of Tobl in different tissues of adult pigs. The tissues examined were (1) lung; (2) biceps femoris; (3) spleen; (4) heart; (5) stomach; (6) large intestine; (7) lymph; (8) small intestine; (9) liver; (10) brain; (11) longissimus dorsi (LD); (12) kidney; (13) fat; (14) gastrocnemius; and (15) semitendinosus. The values shown are Mean \pm SD levels of Tobl from three independent experiments. The level of Tob1 in spleen was arbitrarily set to 1.0 .

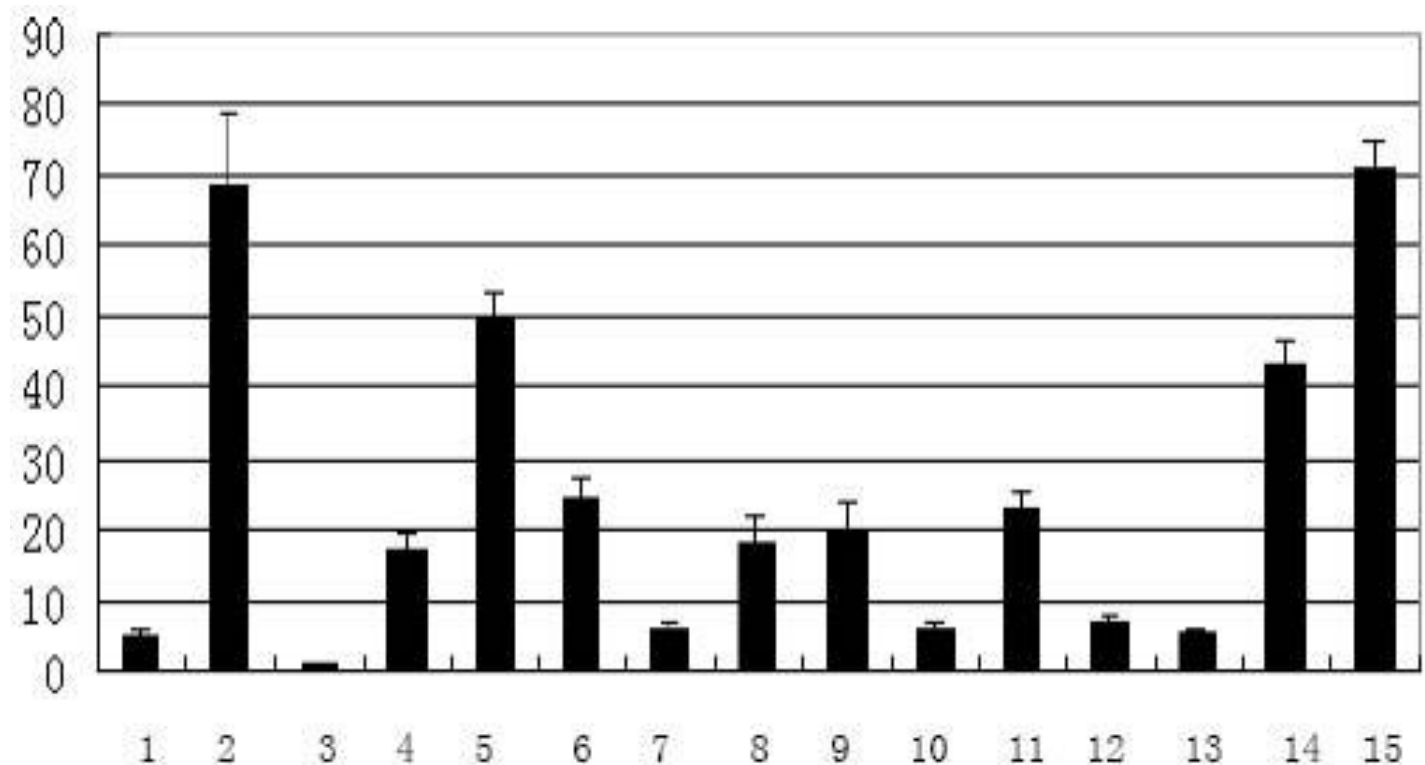

\subsection{Tob1 Expression During C2C12 Differentiation Time}

We investigated the expression of Tob1 during $\mathrm{C} 2 \mathrm{C} 12$ myoblast differentiation time using Real-time PCR with GAPDH as an internal control. The statistics were Student's $t$-test of $1-7$ day during differentiation time compared to 0 day. The expression of Tobl was significantly increased at day 6 during $\mathrm{C} 2 \mathrm{C} 12$ differentiation time $(p<0.05)$, suggesting its role in skeletal muscle development (Figure 4). This further suggested that Tobl was perhaps involved in myoblast differentiation. 
Figure 4. Expression pattern of the mouse Tobl gene during $\mathrm{C} 2 \mathrm{C} 12$ differentiation time. The values were normalized to GAPDH mRNA expression level. Day 0 expression level was set to 1 . The error bars indicate Mean \pm SD $(n=3)$. 0: C2C12 myoblast cells; 1-7: days $1-7$ of myoblast differentiation into myotubes.

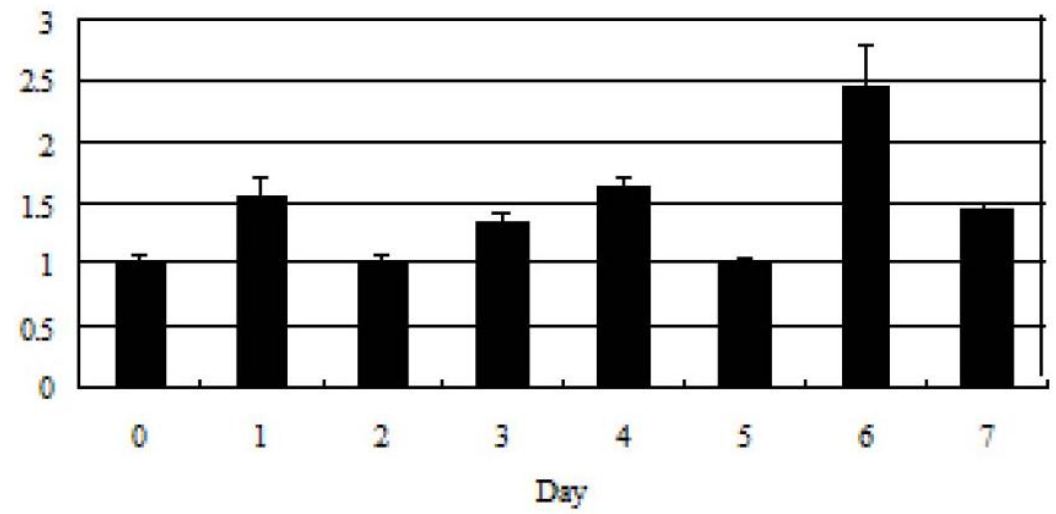

\subsection{Chromosome Mapping Using IMpRH}

Using the INRA-University of Minnesota porcine radiation hybrid panel ( IMpRH panel), we found that the swine Tob1 gene was closely linked (two-point analysis) to the microsatellite marker SS04H11 on pig chromosome 12 (SSC12). The SS04H11 marker was mapped to 12p11-p13; therefore, the most likely chromosomal location for Tobl was assigned as 12p11-p13 (Table 2). Pig chromosome 12 accounted for $3.5 \%$ of the pig genome, corresponded to human chromosome 17. The human Tobl gene was mapped to chromosome 17 (SSC17), which was in agreement with the above conclusion.

Table 2. RH mapping results for the swine Tobl gene.

\begin{tabular}{lllllll}
\hline Gene & $\begin{array}{l}\text { Retention } \\
\text { fraction\% }\end{array}$ & Chromosome & $\begin{array}{l}\text { Linked } \\
\text { marker }\end{array}$ & $\begin{array}{l}\text { Breakage } \\
\text { frequency }\end{array}$ & $\begin{array}{l}\text { RH } \\
\text { distance(Ray) }\end{array}$ & $\begin{array}{l}\text { LOD } \\
\text { score }\end{array}$ \\
\hline Tobl & 27 & 12 & SS04H11 & 0.5 & 0.69 & 5.52 \\
\hline
\end{tabular}

\subsection{Subcellular Localization of Tob1 in PK15 Cells}

To determine the subcellular localization of Tob1, we transfected pEGFP-Tob1 plasmid into PK15 cells. PSORT II program analysis predicted that Tob1 may be localized primarily to the nucleus (65.2\% probability), with lower probabilities found for the cytoplasm (8.7\%), plasma membrane (4.3\%). But our analysis of pEGFP-Tob1 fusion protein indicated that the pEGFP-Tob1 fusion protein was distributed throughout the nucleus and cytoplasm of the PK15 cells using fluorescence microscopy. Green fluorescence was detected through control cells transfected with GFP vector alone (Figure 5).

In human Tob1, Tob1 was shuttling between the nucleus and the cytoplasm by its nuclear localization signal (NLS) and nuclear export signals (NES) [19], NLS and NES played important roles in subellular distribution [19,20]. When the cells stayed at G0 phase, Tob1 was mainly localized in the nucleus. Until early G1 phase, most of Tob1 protein still localized in the nucleus, but when the cells entered into the late $\mathrm{S}$ phase, more than half of Tob1 protein was detected in the cytoplasm [18], which suggested that the subcellular distribution of Tob1 also varied with cell cycle. It seemed that 
mechanisms of nuclear versus cytoplasmic localization of Tob1 protein will have some effects on its anti-proliferative function.

Figure 5. Subcellular localization of the pEGFP-Tob1 fusion protein in PK15 cells. (A) Distribution of fluorescence after transfection of the pEGFP-Tob1 vector; (B) PK15 nuclei stained with Hoechst 33342; (C) The merged image of A and B; (D) GFP detected in PK15 cells transfected by the pEGFP-N3 empty vector; (E) Nuclei of PK15 cells transfected by the pEGFP-N3 empty vector; (F) The merged image of D and E.

(A)

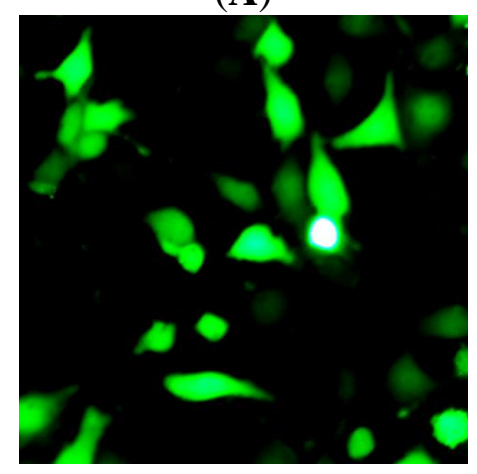

(D)

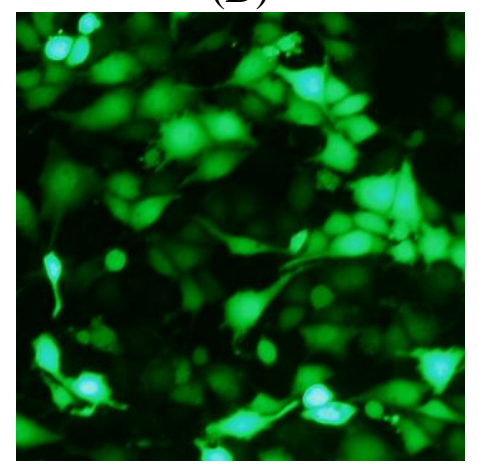

(B)

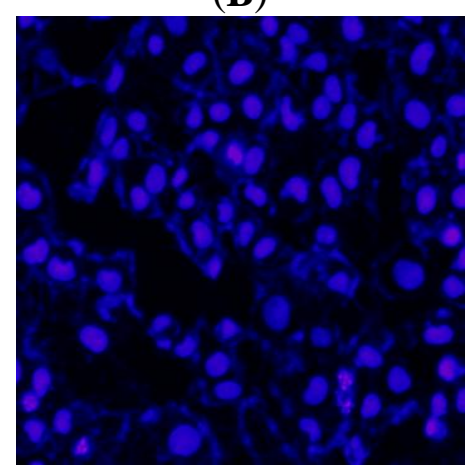

(E)

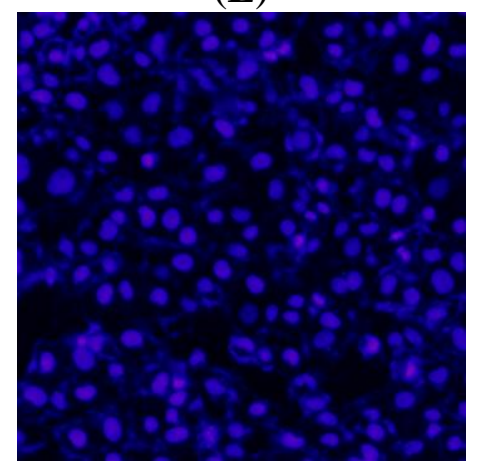

(C)

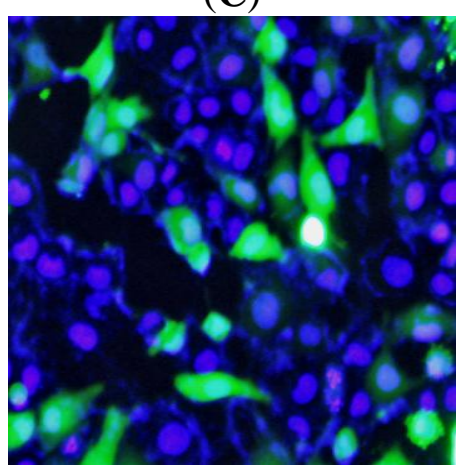

(F)

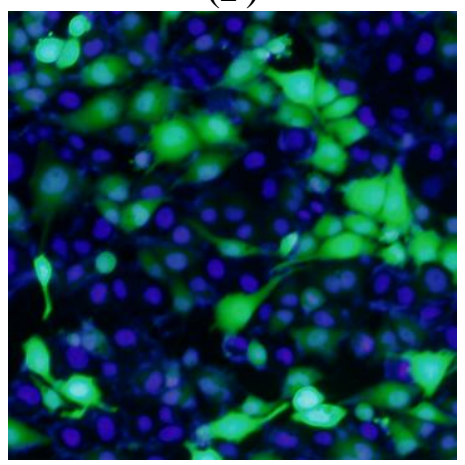

\section{Experimental Section}

\subsection{Source of Animals and Tissues}

Pig embryos or fetuses were collected from pregnant Tongcheng and Landrace pigs during three embryonic periods (33, 65 and 90 days post-conception, dpc) and three postnatal periods (day 2, day 28 and adults period). The longissimus dorsi (LD) muscles were isolated. The different fifteen tissues were acquired from mature Wuzhishan miniature pigs for expression pattern analysis. All the tissue samples were collected from three individual pigs at each period. All the tissues were harvested, frozen in liquid nitrogen, and stored at $-80^{\circ} \mathrm{C}$ until use.

\subsection{RNA Extraction and cDNA Preparation}

Total RNA was isolated using Trizol reagent (Invitrogen, Carlsbad, CA, USA), according to the manufacturer's instructions. RNA measurement was conducted using Evolution $60 \mathrm{UV}-\mathrm{Visible}$ spectrophotometer (Thermo Fisher Scientific Inc, Portsmouth, NH, USA) by measuring ultraviolet absorbance at $260 \mathrm{~nm}$ and $280 \mathrm{~nm}$. Calculation of the RNA concentration was based on the absorbance at 
$260 \mathrm{~nm}$. Furthermore, RNA purity was estimated as the $260 \mathrm{~nm} / 280 \mathrm{~nm}$ ratio, and the RNA samples were then stored at $-80{ }^{\circ} \mathrm{C}$.

The cDNAs were reverse-transcribed from RNAs using an oligo(dT) primer and M-MLV reverse transcriptase (Promega, Madison, WI, USA). The conditions were as follows: 5 min at $37{ }^{\circ} \mathrm{C}$ followed by $60 \mathrm{~min}$ at $42{ }^{\circ} \mathrm{C}$ and $10 \mathrm{~min}$ at $72{ }^{\circ} \mathrm{C}$. The resulting cDNA samples were stored at $-20{ }^{\circ} \mathrm{C}$.

\subsection{Cloning, Sequencing and Analysis of Tob1 mRNA Sequences}

A BLAST search was performed to obtain pig ESTs based on the human Tob1 mRNA sequence (GenBank: NM_005749.2), and mRNA sequence of the swine Tobl gene was obtained by assembling ESTs with more than $80 \%$ identity to the human mRNA sequence. The partial mRNA sequence of swine Tobl was amplified with Tob1F, R primers (Table 3) using skeletal muscle cDNA as template. The PCR product was purified and subsequently cloned into the pGEM T-easy vector (Takara, Otsu, Japan) and sequenced using M13-forward and M13-reverse primers.

Table 3. Primers and probes used in these experiments.

\begin{tabular}{|c|c|c|c|}
\hline Primer & Sequences (5'-3') & Size (bp) & $\mathbf{T m}\left({ }^{\circ} \mathbf{C}\right)$ \\
\hline Tob1F & AAGCAGCCCGAACAAGAC & \multirow{2}{*}{1462} & \multirow{2}{*}{55.6} \\
\hline Tob1R & AATCAGCCATGTCCTTGC & & \\
\hline Tob1-MF & GACCCCGTCCTCGCCAAC & \multirow{2}{*}{170} & \multirow{2}{*}{64} \\
\hline Tob1-MR & TGTTCGGGCTGCTTCCACC & & \\
\hline GLGIF & CATGCAGTATTCTAACCAGCA & \multirow{2}{*}{60} & \multirow{2}{*}{54.4} \\
\hline GLGIR & ACTATCTAGAGCGGCCGCTT & & \\
\hline Exp-F & TGATCGAGCAGGCATCCAA & \multirow{2}{*}{116} & \multirow{2}{*}{58} \\
\hline Exp-R & TTCGCCGATCTGGTAGGAAAC & & \\
\hline GAPDH-F & GGTGAAGGTCGGAGTGAACG & \multirow{2}{*}{233} & \multirow{2}{*}{60} \\
\hline GAPDH-R & CTCGCTCCTGGAAGATGGTG & & \\
\hline Loc-F & AGCGCTATGCAGCTTGAAATCCAAGTAG & \multirow{2}{*}{1038} & \multirow{2}{*}{61} \\
\hline Loc-R & AGATCTGTTAGCCATAACAGGCTGGAAT & & \\
\hline $\begin{array}{l}\text { Tob1F, R: } p \\
\text { analyze the } \\
\text { Tob1 cDNA } \\
\text { C2C12 cells; } \\
\text { the expressio }\end{array}$ & $\begin{array}{l}\text { ence; Exp-F, R: primers used to analyze the express } \\
\text { DH-F, R: primers used as an internal control; Loc-F, } \\
\text { ctor pEGFP-Tob1. }\end{array}$ & $\begin{array}{l}\text { F, MR: prim } \\
\text { levelify the } 3 \\
\text { level of mo } \\
\text { rimers used }\end{array}$ & $\begin{array}{l}\text { ers used to } \\
\text { end of the } \\
\text { se Tobl in } \\
\text { o construct }\end{array}$ \\
\hline
\end{tabular}

The protein domain analysis was performed using PSORT II [21] and PROSITE [22].

\subsection{Isolation of 3' cDNA by GLGI}

To identify the tag sequence and obtain the 3' UTR sequence of the swine Tobl gene, the LongSAGE tag of $17 \mathrm{bp}$ (CAGTATTCTAACCAGCA) was changed into its corresponding 3' UTR sequence using the GLGI method (the generation of longer cDNA fragments from SAGE tags by converting novel SAGE tags into 3' cDNAs for gene identification, GLGI) [23]. The GLGI experiment was carried out as previously reported $[16,24]$. The PCR product was sequenced and aligned for gene sequence identification. 


\subsection{TaqMan Real-Time PCR Analysis}

We analyzed the dynamic expression profile in prenatal skeletal muscle $(33,65$ and 90 days post-conception, dpc) from Landrace and Tongcheng pigs. The expression of Tob1 in postnatal skeletal muscle ( 2 day, 28 day and adults) from Tongcheng pigs and all kinds of tissues in adult wuzhishan miniature pigs were also examined using TaqMan real-time PCR.

The TaqMan real-time PCR system contained $10 \times$ PCR buffer (Takara, Otsu, Japan), $3.0 \mathrm{mM}$ $\mathrm{MgCl}_{2}, 100 \mu \mathrm{M}$ each dNTP, $0.3 \mu \mathrm{M}$ primers, $0.1 \mu \mathrm{M}$ probe, $2 \mathrm{U}$ Taq DNA polymerase (Takara, Otsu, Japan), $2 \mu \mathrm{L}$ cDNA template, add ultrapure water to a total volume of $20 \mu \mathrm{L}$. The cycling conditions consisted of an initial cycle of $5 \mathrm{~min}$ at $95{ }^{\circ} \mathrm{C}$ followed by 35 cycles of $15 \mathrm{~s}$ at $95{ }^{\circ} \mathrm{C}$ and $1 \mathrm{~min}$ at $60{ }^{\circ} \mathrm{C}$. The PCR reactions were performed in biological triplicate for each sample. The gene expression levels were quantified relative to the expression of GAPDH using Gene Expression Micro (Bio-Rad, Richmond, VA, USA) employing the comparative cycle threshold ( $\Delta \Delta \mathrm{Ct})$ method [25].

\subsection{Real-Time PCR Analysis During C2C12 Differentiation Time}

$\mathrm{C} 2 \mathrm{C} 12$ established from normal adult $\mathrm{C} 3 \mathrm{H}$ mouse leg muscle, was good model to study myogenesis and cell differentiation in vitro.

The cells were cultured in Dulbecco's modified Eagle's medium (DMEM) supplemented with 10\% (v/v) FBS, $2 \mathrm{mM}$ glutamine, $100 \mathrm{U} / \mathrm{mL}$ penicillin and $100 \mu \mathrm{g} / \mathrm{mL}$ streptomycin and maintained at $37{ }^{\circ} \mathrm{C}$ in $5 \% \mathrm{CO}_{2}$. To induce myogenic differentiation, $\mathrm{C} 2 \mathrm{C} 12$ cells were seeded in six-well plates. After about 12-16 h, when cell confluence reached approximately 60-70\%, the differentiation of C2C12 myoblasts into myotubes was induced by the addition of differentiation medium (DMEM contained $2 \%$ horse serum instead of $10 \%$ FBS). We collected the cells for RNA extraction and H.E staining every day during $\mathrm{C} 2 \mathrm{C} 12$ differentiation time. The myotubes were confimed by H.E staining in morphological level and creatine kinase muscle (CKM) marker in biochemical characterization.

The Real-time PCR system contained $50 \times$ ROX Reference Dye II, $2 \times$ SYBR Green Real-Time PCR Master Mix (Takara, Otsu, Japan), $10 \mu \mathrm{M}$ primers and $1 \mu \mathrm{L}$ cDNA template in a total volume of $20 \mu \mathrm{L}$. The cycling conditions consisted of an initial step of $15 \mathrm{~s}$ at $95{ }^{\circ} \mathrm{C}$ followed by 40 cycles of $5 \mathrm{~s}$ at $95{ }^{\circ} \mathrm{C}$ and $34 \mathrm{~s}$ at $62{ }^{\circ} \mathrm{C}$. The PCR reactions were performed in an ABI 7500 FAST Real-time PCR instrument in biological triplicate for each sample. The gene expression levels were normalized to GAPDH as described above.

\subsection{Chromosome Mapping Using IMpRH}

The chromosome assignment was performed using the INRA-University of Minnesota 7000-rad radiation hybrid panel (IMpRH) consisting of 118 hamster-swine hybrid cell lines [26]. The PCR reaction was carried out in a total volume of $10 \mu \mathrm{L}$ containing $10 \times$ PCR buffer $\left(\mathrm{Mg}^{2+}\right.$, Fermentas, Burlington, ON, Canada), $75 \mu \mathrm{M}$ each dNTP, $0.3 \mu \mathrm{M}$ each primer, $25 \mathrm{ng}$ panel DNA, and $1.0 \mathrm{U}$ Taq DNA polymerase (Fermentas, Burlington, ON, Canada). The PCR conditions were $94{ }^{\circ} \mathrm{C}$ for 3 min, 35 cycles of $20 \mathrm{~s}$ at $94{ }^{\circ} \mathrm{C}, 20 \mathrm{~s}$ at $62{ }^{\circ} \mathrm{C}$, and $20 \mathrm{~s}$ at $72{ }^{\circ} \mathrm{C}$, and a final extension of $5 \mathrm{~min}$ at $72{ }^{\circ} \mathrm{C}$. The data analysis was performed using the IMpRH [27]. 


\subsection{Construction of the Subcellular Localization Vector}

We used Loc-F/Loc-R primers (Table 3) to amplify the full coding sequence of the Tobl gene. ECO47III and BglII restriction sites were incorporated at the 5' ends of the forward and reverse primer, respectively. After T-A cloning, the PCR fragment was double-digested using ECO47III and BglII. The product was then inserted into the linear pEGFP-N3 vector, which was digested using the same enzymes (MBI, Houston, TX, USA), to generate the pEGFP-Tob1 plasmid. Subsequently, pEGFP-Tob1 was sequenced by Invitrogen to verify the sequence of the inserted fragment.

\subsection{Cell Culture and Transient Transfection}

Pig kidney cells (PK15) were seeded in six-well plates and cultured in DMEM supplemented with $10 \% \mathrm{FBS}, 4 \mathrm{mM}$ glutamine, $100 \mathrm{U} / \mathrm{mL}$ penicillin and $100 \mathrm{U} / \mathrm{mL}$ streptomycin at $37{ }^{\circ} \mathrm{C}$ in $5 \% \mathrm{CO}_{2}$.

When the cells had reached approximately $80 \%$ confluence, we performed transient transfections using $10 \mu \mathrm{L}$ Lipofectamine 2000 reagent (Invitrogen, Carlsbad, CA, USA) with $4 \mu \mathrm{g}$ of pEGFP-Tob1 or pEGFP-N3 plasmid DNA (Promega, Madison, WI, USA). The transfection medium was replaced with normal growth medium after $6 \mathrm{~h}$. At $24 \mathrm{~h}$ after transfection, the cells in 6-well plate were washed three times using phosphate-buffered saline, then fixed for 15 min with $4 \%$ para-formaldehyde. After the washing steps, the cells were stained with $10 \mu \mathrm{M}$ Hoechst 33342 for $10 \mathrm{~min}$. The subcellular localization of the pEGFP-Tob1 fusion protein was determined using fluorescence microscopy.

\section{Conclusions}

In conclusion, we isolated and characterized the swine Tobl gene. Subsequently, we examined Tobl chromosome assignment, subcellular localization and dynamic expression profile in prenatal skeletal muscle. Our data indicated that the swine Tobl gene was differentially expressed throughout skeletal muscle development, which suggested a role for Tobl in the regulation of skeletal muscle development. It also exhibited different expression patterns between Tongcheng (obese-type) and Landrace (lean-type) pigs during myogenesis, the Tobl gene was highly expressed in skeletal muscle at $90 \mathrm{dpc}$ in Tongcheng pigs and it was much higher than that in Landrace pigs. These findings suggested that the Tobl gene contributed to phenotypic differences in muscle between Chinese and foreign breeds of pigs and should be considered as a candidate gene for meat production traits.

Taken together, our findings will provide a basis for future study on Tobl function in regulation of skeletal muscle development.

\section{Acknowledgements}

We are grateful to Mo Delin for providing the help in Quantitative PCR experiment. This research was supported by the National Natural Science Foundation of China (30830080) and National Key Basic Research Program (2009CB941604) and National Key Project (2008ZX08009-001). 


\section{References}

1. Matsuda, S.; Rouaul, J.; Magaud, J.; Berthet, C. In search of a function for the TIS21/PC3/BTG1/TOB family. FEBS Lett. 2001, 49, 67-72.

2. Miller, C.W.; Koeffle, H.P. Cyclin-dependent kinase inhibitors in human neoplasms. Leukemia 1997, 11, 370-371.

3. Sasajim, H.; Nakagawa, K.; Yokosawa, H. Anti-proliferative proteins of the BTG/Tob family are degraded by the ubiquitin-proteasome system. Eur. J. Biochem. 2002, 269, 3596-3604.

4. Feng, Z.; Tang, Z.L.; Li, K.; Liu, B.; Yu, M.; Zhao, S.H. Molecular characterization of the BTG2 and BTG3 genes in fetal muscle development of pigs. Gene 2007, 403, 170-177.

5. Matsuda, S.; Kawamura, T.J.; Ohsugi, M.; Yoshida, M.; Emi. M.; Nakamura, Y.; Onda, M.; Yoshida, Y.; Nishiya, A.; Yamamoto, T. Tob, a novel protein that interacts with p185erbB2, is associated with anti-proliferative activity. Oncogene 1996, 12, 705-713.

6. Suzuk, T.; Tsuzuku, J.K.; Ajim, R.; Nakamura, T.; Yoshida, Y.; Yamamoto, T. Phosphorylation of three regulatory serines of Tob by Erk1 and Erk2 is required for Ras-mediated cell proliferation and transformation. Gene. Develop. 2002, 16, 1356-1370.

7. Tzachanis, D.; Freema, G.J.; Hirano, N.; Van Puijenbroek, A.A.; Delfs, M.W.; Berezovskaya, A.; Nadler, L.M.; Boussiotis, V.A. Tob is a negative regulator of activation that is expressed in anergic and quiescent T cells. Nat. Immunol. 2001, 2, 1174-1182.

8. Maekawa, M.; Nishida, E.; Tanoue, T. Identification of the antiproliferative protein Tob as a MAPK substrate. J. Biol. Chem. 2002, 277, 37783-37788.

9. Jin, M.; Wang, X.M.; Tu, Y.; Zhang, X.H.; Gao, X.; Guo, N.; Xie, Z.; Zhao, G.; Jing, N.; Li, B.M.; $\mathrm{Yu}, \mathrm{L}$. The negative cell cycle regulator, Tob (transducer of ErbB2), is a multifunctional protein involved in hippocampus-dependent learning and memory. Neuroscience 2005, 131, 647-659.

10. Yoshida, Y.; Tanaka, S.; Umemori, H.; Minowa, O.; Usui, M.; Ikematsu, N.; Hosoda, E.; Imamura, T.; Kuno, J.; Yamashita, T.; Miyazono, K.; Noda, M.; Noda, T.; Yamamoto, T. Negative regulation of BMP/Smad signaling by Tob in osteoblasts. Cell 2000, 103, 1085-1097.

11. Jia, S.J.; Meng, A.M. Tob genes in development and homeostasis. Develop. Dynam. 2007, 236, 913-921.

12. Yoshida, Y.; Nakamura, T.; Komoda, M.; Satoh, H.; Suzuki, T.; Tsuzuku, J.K.; Miyasaka, T.; Yoshida, E.H.; Umemori, H.; Kunisaki, R.K.; Tani, K.; Ishii, S.; Mori, S.; Suganuma, M.; Noda, T.; Yamamoto, T. Mice lacking a transcriptional corepressor Tob are predisposed to cancer. Gene. Dev. 2003, 17, 1201-1206.

13. Iwanaga, K.; Sueoka, N.; Sato, A.; Sakuragi, T.; Sakao, Y.; Tominaga, M.; Suzuki, T.; Yoshida, Y.; K-Tsuzuku, J.; Yamamoto, T.; Hayashi, S.; Nagasawa, K.; Sueoka, E. Alteration of expression or phosphorylation status of Tob, a novel tumor suppressor gene product, is an early event in lung cancer. Cancer Lett. 2003, 202, 71-79.

14. Shi, K.H.; Zhang, L.X.; Meng, A.M. Cloning and expression analysis of zebrafish Tob1 gene. Dev. Genes Evol. 2004, 214, 309-311.

15. Xiong, B.; Rui, Y.; Zhang, M.; Shi, K.; Jia, S.; Tian, T.; Yin, K.; Huang, H.; Lin, S.; Zhao, X.; Chen, Y.; Chen, Y.G.; Lin, S.C.; Meng, A.M. Tob1 controls dorsal development of zebrafish embryos by antagonizing maternal betacatenin transcriptional activity. Dev. Cell 2006, 11, 225-238. 
16. Tang, Z.L.; Li, Y.; Wan, P.; Li, X.P.; Zhao, S.H.; Liu, B.; Fan, B.; Zhu, M.J.; Yu, M.; Li, K. LongSAGE analysis of skeletal muscle at three prenatal stages in Tongcheng and Landrace pigs. Genome Biol. 2007, 8, R115.

17. Yoshida, Y.; Matsud, S.; Yamamoto, T. Cloning and characterization of the mouse Tob gene. Gene 1997, 191, 109-113.

18. Kent, W.J.; Sugnet, C.W.; Furey, T.S.; Roskin, K.M.; Pringle, T.H.; Zahler, A.M.; Haussler, D. The human genome browser at UCSC. Genome Res. 2002, 12, 996-1006.

19. Kawamura-Tsuzuku, J.; Suzuki, T.; Yoshida, Y.; Yamamoto, T. Nuclear localization of Tob is important for regulation of its antiproliferative activity. Oncogene 2004, 23, 6630-6638.

20. Maekawa, M.; Yamamoto, T.; Nishida, E. Regulation of subcellular localization of the antiproliferative protein Tob by its nuclear export signal and bipartite nuclear localization signal sequences. Exp. Cell Res. 2004, 295, 59-65.

21. Boeckmann, B.; Bairoch, A.; Apweiler, R.; Blatter, M.C.; Estreicher, A.; Gasteiger, E.; Martin, M.J.; Michoud, K.; O’Donovan, C.; Phan, I.; Pilbout, S.; Schneider, M. The SWISS-PROT protein knowledgebase and its supplement TrEMBL in 2003. Nucl. Acids Res. 2003, 31, $365-370$.

22. Gasteiger, E.; Gattiker, A.;Hoogland, C.; Ivanyi, I.; Appel, R.D.; Bairoch, A. ExPASy: The proteomics server for in-depth protein knowledge and analysis. Nucl. Acids Res. 2003, 31, 3784-3788.

23. Chen, J.; Sun, M.; Lee, S.; Zhou, G.; Rowley, J.D.; Wang, S.M. Identifying novel transcripts and novel genes in the human genome by using novel SAGE tags. Proc. Nat. Acad. Sci.USA 2002, 99, 12257-12262.

24. Tang, Z.L.; Li, Y.; Zhao, S.H.; Liu, B.; Fan, B.; Li, K. A modified GLGI method for identification of novel porcine genes from long serial analysis of gene expression tags. Chin. J. Agr. Biotechnol. 2007, 4, 111-115.

25. Livak, K.J.; Schmittgen, T.D. Analysis of relative gene expression data using real-time quantitative PCR and the 2(-Delta Delta C(T)) method. Methods 2001, 25, 402-408.

26. Yerle, M.; Pinton, P.; Robic, A.; Alfonso, A.; Palvadeau, Y.; Delcros, C.; Hawken, R.; Alexander, L.; Beattie, C.; Schook, L.; Milan, D.; Gellin, J. Construction of a whole-genome radiation hybrid panel for high-resolution gene mapping in pigs. Cytogenet. Cell Genet. 1998, 82, 182-188.

27. Milan, D.; Hawken, R.; Cabau, C.; Leroux, S.; Genet, C.; Lahbib, Y.; Tosser, G.; Robic, A.; Hatey, F.; Alexander, L.; Beattie, C.; Schook, L.; Yerle, M.; Gellin, J. IMpRH server: An RH mapping server available on the web. Bioinformatics 2000, 16, 558-559.

(C) 2011 by the authors; licensee MDPI, Basel, Switzerland. This article is an open access article distributed under the terms and conditions of the Creative Commons Attribution license (http://creativecommons.org/licenses/by/3.0/). 